ESTUDOS RBE?

\title{
Diários de viagem de Anísio Teixeira: razões e sentidos de uma escrita de "si" e do "outro""
}

\author{
Silmara Fátima Cardoso
}

\section{Resumo}

Tem por pretensão analisar dois diários produzidos por Anísio Teixeira em suas viagens à Europa em 1925 e aos Estados Unidos em 1927. O viajante lança mão da escrita diária para registrar o cotidiano a bordo, ações de sujeitos, aspectos das cidades, suas reflexões em relação à vida, a si, à política, à educação, à religião católica, à América, além dos objetivos e propósitos de suas viagens. Utilizando esses diários como fonte privilegiada de estudo, a autora busca compreender como Anísio Teixeira representa e projeta na sua escrita uma imagem de "si" e do "outro" e explicita estar consciente das dificuldades em analisar e interpretar essas fontes, já que, conforme afirma Umberto Eco, "um texto é um universo indefinidamente aberto em que o intérprete pode descobrir interligações infinitas", sendo a linguagem "incapaz de apreender um sentido único e preexistente".

Palavras-chave: diários de viagem; representações de "si" e do "outro"; Anísio Teixeira.

* Texto publicado nos Anais do $26^{\circ}$ Simpósio Nacional de História, realizado em São Paulo, em 2011. 


\section{Abstract \\ Travel Diaries of Anísio Teixeira's: reasons and ways of writing a "self" and the "other"}

This text is analyzing two daily claims that have been produced by Anísio Teixeira in his travels to Europe in 1925 and the United States in 1927. The traveler makes use of writing to record the daily routine on board actions subject, aspects of cities, their reflections on life, to you, ya politics, education, religion Catholic, America, and the goals and purposes their travels. Using these journals as a privileged source of study, I seek to understand how Anísio Teixeira represents in his writing and projects an image of "self" and "other." It is necessary to clarify that I am aware of the difficulties in analyzing and interpreting these sources. According to Eco (2005) a text is an open universe indefinitely, in which the player can discover endless interconnections. Language is unable to grasp a single, pre-existing sense.

Keywords: travel diaries; representations of "self" and "other"; Anísio Teixeira.

Anísio Teixeira, quando ocupava o cargo de Diretor-Geral de Instrução Pública da Bahia, em 1925, obteve permissão do governador Francisco Marques de Góes Calmon para acompanhar D. Augusto - o primaz arcebispo da Bahia - nas comemorações do Ano Santo, em Roma, atendendo um apelo do papa, que convocava os fiéis para realizarem uma peregrinação percorrendo a via-sacra do itinerário católico: Portugal, Espanha, Itália, França, Palestina. Anísio aproveita sua viagem para passear por algumas cidades europeias e, também, visitar algumas instituições educativas.

A viagem ao Novo Mundo em 1927 é de caráter oficial. Anísio havia sido designado pelo governador da Bahia para ir aos Estados Unidos da América observar os métodos de ensino e as instituições de educação que poderiam vir a ser implantadas de modo parecido no Estado baiano.

Dessas viagens, Anísio produziu dois diários os quais utilizo como fonte privilegiada de estudo neste trabalho, buscando compreender como Anísio representa e projeta na sua escrita uma imagem de si e do outro.

É possível, nos diários de Anísio, identificar pistas que nos revelam modalidades do seu pensamento. No diário de viagem à Europa, ele se mostra ainda um sujeito conservador, admirador da monarquia, dos monumentos católicos, da educação católica, das coisas simples da vida. Já no diário de viagem aos Estados Unidos observa-se uma oscilação no seu pensamento: ainda que seja a favor de um regime monárquico, volta o 
seu pensamento à República; ainda que se mostre a favor de uma educação católica e dualista, parece aprovar a educação laica e encaminha-se para a defesa de uma educação para todos; ainda que estejam intactos os seus princípios religiosos, os laços que o prendiam ao catolicismo estão fracos.

No diário de viagem aos Estados Unidos, Anísio atenta especialmente para os americanos. Durante seu percurso a bordo ele constrói uma narrativa que pretendia dizer quem é o "outro", e, certamente, dizendo o "outro", estaria representando a si. Ao escrever sobre eles, demonstra grande admiração, considerando-os de mentes modernas e vencedores pela ciência, pela educação e pelo trabalho, mas logo então muda seu posicionamento. Sente repugnância por seus modos de se comportar, falar, agir, vestir, gostos e preferências, que fogem totalmente aos seus padrões de uma cultura europeia aprendida em família e nos colégios jesuítas em que estudou durante boa parte de sua vida.

É necessário explicitar que estou consciente das dificuldades em analisar e interpretar essas fontes. Segundo Eco (2005), "um texto é um universo indefinidamente aberto, no qual o intérprete pode descobrir interligações infinitas. A linguagem é incapaz de apreender um sentido único e preexistente".

Os diários de viagem, por seu caráter privado, estendem inúmeras armadilhas. A impressão de pegar desprevenido o autor, cuja escrita se destinava unicamente a si, o sentimento de violar uma intimidade, garantia de autenticidade, quando não de verdade, são bastante enganadores.

\section{Diários de viagem à Europa e aos Estados Unidos}

As viagens, de acordo com Mignot (2007, p. 247), "geralmente são acompanhadas de recordações e registros escritos, como diários, agendas, cartas e postais, que detalham experiências ou apenas flagram instantes".

Anísio foi um viajante que se valeu intensamente da escrita diária para registrar os acontecimentos durante o seu percurso a bordo e depois dele. Produziu muitos registros, entre eles os seus diários de viagem em terras estrangeiras.

O diário produzido em viagem à Europa contém 56 folhas em papel timbrado Nordentscher Lloyd Bremen Na Bord des D., Sierra Morena" e S. S Gelria. O diário produzido em viagem aos Estados Unidos contém 52 folhas em papel timbrado Munson Steamship Lines. Eles contam uma história pessoal. Trazem descritos aspectos das culturas europeia e americana. Relatam histórias de lugares e ações de sujeitos. ${ }^{1}$

Quanto ao modo de construção do texto e da escrita, aproximam-se de um ensaio. Anísio deixou registrado, de forma mais livre e "sincera", os seus pensamentos, ideias e sentimentos.

O ensaio oferece mais liberdade ao escritor, no sentido de orientar sua escrita pelo pensamento, sem obrigação de seguir algum plano preestabelecido, código, regra ou convenção. As temáticas tratadas estão atreladas às suas opiniões e pontos de vista, representando o seu modo
${ }^{1}$ Os diários, microfilmados, são disponibilizados pelo CPDOC para consulta e impressão na própria instituição. 
de ser e pensar. Anísio transpõe para seus escritos as escolhas pessoais, crenças e propósitos. Por isso, na forma ensaística, memória e vida se confundem em pensamento.

Uma escrita ensaística inclui a representação do "eu", algo próprio do autor, uma marca na sua experiência vivida. Engendra um texto com digressões e relatos próprios dos acontecimentos cotidianos. Surge da reflexão solitária, sendo possível ao escrevente conhecer a si mesmo e rever as próprias posições. Desse modo, por meio de sua escrita, Anísio está descobrindo na solidão a bordo uma nova dimensão de si mesmo.

Anísio produziu sua escrita em folhas avulsas/soltas, ${ }^{2}$ apresentando marcas da oralidade - rasuras, abreviações, elementos metafóricos e subjetivos. Isso se justifica pelo fato de sua escrita diarística ser livre e sem intenções primeiras de um leitor.

Nos escritos de viagem à Europa encontramos sessenta rasuras e nos de viagem aos Estados Unidos da América, quarenta e sete. Segundo Pino (2004), a rasura tem a função de permitir uma nova consistência, que elimina, ao menos parcialmente, uma angústia do escritor.

O uso de abreviações é muito utilizado, demonstrando liberdade na hora de escrever: snr (senhor), Dr. (doutor), Comm. (comandante), Ex. (Excelência, refererindo-se ao bispo Don Augusto), Comp. (Companhia, referindo-se ao navio em que viaja), $\mathrm{m}^{\mathrm{a}}{ }^{\mathrm{a}}$ intelle (minha inteligência), my coração (meu coração), do q q p. ${ }^{a}$ (do que qualquer pessoa), my espirito (meu espírito), extrang (estrangeiro), Vossa pág de alb em q a s.t ${ }^{\mathrm{a}}$ me pede para deixar o my autogr. (Vossa página de álbum em que a senhorita me pede para deixar o meu autógrafo).

Anísio também usa palavras estrangeiras (francês, espanhol e inglês). Isso demonstra que, além de ser conhecedor dessas línguas, a situação daquele momento - a viagem - o fez usar palavras dos países a que se destinava: viejo, chauffer, metteur em scéne, títere, grand guignol, footh, Sport, chairnau of sports, rounds, hard book, sans façon, toilettes, races horses, american shocks, ruellas, waiter, my.

Essa documentação está localizada no seu arquivo pessoal sob a guarda do CPDOC e é classificada como "Anotações de viagem". Alguns autores, como Nunes (2000), Mignot e Gondra (2006) e Carvalho (2003), entre outros, classificam-na como "diário de viagem" ou "diário de bordo".

Neste trabalho também vamos considerar a documentação como diário, por se tratar de um objeto pessoal que segue uma datação e tem como finalidade principal situar os acontecimentos no tempo. A escrita é fragmentada e descontínua; os assuntos não estão necessariamente interligados. Apresenta rasuras e abreviações, condições de uma escrita mais informal, e tem por leitor, assim acreditamos, o seu próprio autor.

Que significados vêm à mente quando lançamos mão da palavra diário? O significado mais comum e usual é o de um objeto que contém a narrativa diária de experiências pessoais. Registro das vivências e sentimentos de um "eu" ante o mundo que o rodeia. Possui um caráter intimista e confidente, e protagonista/narrador podem ser coincidentes.
2 Muitos autores começaram seus diários nas margens laterais dos almanaques. Outros surgiram a partir dos chamados Livros de Razão, nos quais se costumava escrever e guardar as prescrições, receitas, fórmulas medicamentosas e maneiras de tratamento, para que não fossem esquecidas ou sofressem alterações acabando por inviabilizar seu uso. A partir da industrialização, no século18, o desenvolvimento da fabricação de papel e das técnicas de encadernação tornou possível a venda de volumes encadernados próprios para os registros íntimos. Hoje, qualquer papelaria vende cadernos específicos para o registro íntimo, com variedade de tamanhos, cores, formatos, muitos ostentando na capa os dizeres "meu diário". 
${ }^{3}$ Grand Tour era o nome dado a uma tradicional viagem pela Europa, feita principalmente por jovens da classe alta. O costume floresceu desde cerca de 1600 até o surgimento do tráfego ferroviário em grande escala, na década de 1840, e costumava estar sempre associado a um determinado itinerário. A tradição ainda continuou depois que as viagens por trem e navio a vapor facilitaram os deslocamentos, e jovens americanos e de outros locais do mundo também a realizaram.
Por esse motivo, a modalidade de enunciação do discurso geralmente é utilizada em primeira pessoa.

A matriz discursiva é muito livre, uma vez que o narrador dá livre expressão ao curso do seu pensamento. Na maioria das vezes, o discurso é subjetivo e a escrita é confessionalista. O nível de língua é familiar e o registro é informal. Por vezes, a narração é descontínua, intercalada, porque apenas ocorre quando o sujeito da enunciação deseja registrar algo.

Viñao (2000) define um diário como uma sucessão de textos mais ou menos extensos, e os registros podem estar em folhas soltas ou juntas em um suporte. É escrito sobre o fio dos acontecimentos, com maior ou menor frequência e regularidade, ao longo dos anos ou durante um período de tempo determinado. $\mathrm{O}$ peso da realidade imediata ainda viva, sobre ou a partir do que se escreve, confere ao diário o caráter fragmentário e atomizado.

Viñao aponta algumas tipologias e funções de diários: íntimos onde predominam os sentimentos e emoções; de viagem - pouco íntimo e pessoal; administrativos ou institucionais - tratam de campanhas, navegação, afazeres; escolares - predominam o cotidiano, a vida escolar de professores e alunos. O autor diz que se limitou a tratar somente destes diários no seu texto, pois há muitos outros ainda.

Neste trabalho tratamos de um diário específico, de viagem. Muito comum no século 18, trazia informações sobre a geografia específica, terreno, possibilidade de rotas, fauna e flora, curiosidades sobre os povos nativos e a expressão do sentimento associado a cada uma dessas experiências. Na metade do século 17 foi muito útil como rito de passagem na educação de rapazes. Uma das etapas para se tornar adulto, o Grand Tour, $^{3}$ oferecia ao jovem a oportunidade de escrever os acontecimentos de sua viagem para desenvolver o hábito da observação e reflexão.

É bem verdade que muitos diários de viagem continham aspectos voltados muito mais para o exterior do que para o "eu" do diarista, embora nesses registros o escrevente fosse capaz de utilizar a escrita para exercitar a autorreflexão e o exame da consciência.

Os diários de Anísio cumprem a função de relatar aspectos do mundo exterior como também para o seu "eu": tanto incluem a objetividade quanto a subjetividade. Além dos aspectos cotidianos, tratam dos sentimentos, opiniões, reflexões, etc.

É possível observar que, nos seus diários, Anísio emite juízo de opinião e de valor. O seu ponto de vista está bem marcado: critica, elogia, defende, condena. Deixa registrado o seu incômodo em relação a muitas questões. Nesta escrita o sujeito está mais à vontade para se expressar, escrever o que bem deseja sem medo de repressões ou opiniões alheias.

Escrever atende necessidades específicas e múltiplas: aproveitar a experiência na sua totalidade, deixar um documento original, que seja útil para outros, guardar melhor as imagens e impressões colhidas ou transmitir acontecimentos e fatos. O ato de registrar é importante, pois permite construir uma memória compreensiva; aquela que não é simples recordação, mas a base para reflexão. 
Anísio pretendia ocupar-se no longo tempo de seu percurso, que seria de duas ou mais semanas em alto mar; assim, ele lança mão de uma escrita diária para escrever sobre "si" e sobre o "outro".

Ele escreveu ainda para desabafar, extravasar seus sentimentos, amenizar suas saudades, suas angústias, sua solidão, anotar impressões, expectativas, mostrar pensamentos, expressar emoções, organizar ideias, elaborar diferenças, expôr dúvidas, fazer comparações, reflexões e questionamentos.

De acordo com Mignot (2003), aprisionar no papel o banal ou o surpreendente da vida cotidiana tem contagiado muitos sujeitos de diferentes gerações, homens ou mulheres, adolescentes, jovens, adultos ou velhos. A escrita diária acontece por muitos motivos e razões diferenciadas.

Apesar de escritos na esfera da intimidade e sem intenção de publicação, os diários esboçam um desejo de comunicação. Anísio escreveu a respeito de coisas sobre as quais gostaria de falar, de refletir, questionar, primeiramente para "si", de repente, para o "outro".

\section{Uma narrativa de "si": representações do pensamento religioso, político e educacional de Anísio Teixeira na sua escrita}

Num primeiro momento, é possível dizer que a intenção maior da viagem de Anísio ao Velho Continente é de propósito religioso - ele parte em companhia de um bispo. Na Espanha visita o santuário de Santo Inácio de Loyola para meditar. Em Roma hospeda-se no Colégio Pio-Americano, o único leigo numa instituição destinada desde 1958 aos padres latinoamericanos, e foi recebido em audiência pessoal, sendo abençoado por Pio X.

No entanto, o viajante parece se ofuscar. Não há o abandono ideal peregrino; o tom doloroso da peregrinação torna-se prazeroso. Em várias ocasiões se distancia da imagem de um católico que busca renunciar aos prazeres mundanos para santificar-se. Ele escreve sobre as belas mulheres de Vigo. A referência a este assunto não cabe nos padrões peregrinos mais ortodoxos:

Mas, de Vigo a impressão realmente foste saudavel e não é de admirar desde que estávamos em terra de Espanha, foi a das suas mulheres. Lindas mulheres de Vigo, tão cheias de saude, de riso e de cores, que sois effectivamente as flores de Espanha, os adornos dessa terra linda que Deus vos deu! Tudo era característico e amável para os olhos. O asseio dos seus trajes vistosos, a insolencia de sua elegancia, o calor dos seus olhos e do seu sangue, o vigor do seu trabalho, tudo constituia para a vista de estrangeiros avidos de impressões, um encanto salubre e rico. Lindas pecadoras, ruidosas lavandeiras de Vigo eu passei por vós apenas a febre de um olhar inquieto e apressado de viajante, mas como vos sou reconhecido pela saudavel impressão espiritual que me fostes, no aereo contentamento de vossos risos altos e no brilho colorido de vossa sadia beleza de hespanholas. (Teixeira, 1925). ${ }^{4}$
4 Foi mantida a escrita original em todas as citações, e, nelas, todos os grifos são do autor. 
No cristianismo, a ideia original de peregrinação é tradicionalmente concebida como jornada penitencial na qual o fiel busca reproduzir o caminho do filho de Deus na Terra. Assim, os crentes se inspiram no trajeto de Jesus, que, feito homem e humilhando-se, foi desprezado, encontrando morte trágica antes de ser glorificado no Reino dos Céus. "Na discursiva cristã, aqui muito influenciada por Agostinho de Hipona, peregrinar seria ascender (arduamente) ao paraíso" (Costa, 2005, p. 144).

O termo peregrinação aos poucos foi se distorcendo do seu sentido original, passando a ser motivo para tão somente conhecer e apreciar a cidade universal do catolicismo. Viajar a Roma no Ano Santo era uma das razões para se deslocar à Europa. A viagem peregrina tinha virado moda, perdia o seu sentido primevo. Muitos membros da elite, principalmente os homens, realizaram este percurso.

Anísio, neste momento, apresenta a imagem de um católico mais moderado. Suas ações demonstram que a ideia de peregrinar não é apenas sacrifício, via dolorosa, mas também prazer e alegria. Assim ele vai redefinindo sua eclesiologia, já não é o crente de antes, almejando uma estrita vida clériga, longe dos atos e atividades "mundanas" e prazerosas.

Apesar de observarmos uma mudança de um novo cristão, ele estava ainda bastante ligado ao catolicismo, religião que amava e admirava por excelência, e procurava nas suas viagens renovar a sua fé de antes. Com exceção de seu pai, Deocleciano Pires Teixeira, convicto republicano e distante de qualquer convicção religiosa, a sua família era de católicos.

Anísio estudara quase toda a sua vida em colégio católico, ainda estava latente a concepção filosófica cristã de sua formação. Segundo Hermes Lima (1978, p. 62), "Anísio educara-se como militante da fé na ambivalência evangelizante da Companhia de Jesus. Ideias, noções, conceitos alicerçavam a crença religiosa sublimada pela devoção à maior glória de Deus".

A viagem à Europa renovou e aumentou o estoque de conhecimento de Anísio Teixeira e o seu capital simbólico. Ele teve a oportunidade de entrar em contato com pessoas, cultura e ideias diferentes, ampliando e enriquecendo o seu universo cultural. Nesse contexto, a viagem é entendida como bem cultural, da mesma forma que Bourdieu (2004) entende a frequência ao teatro, ao concerto, aos museus, cinema, etc.

Em seu percurso pelo Velho Mundo, Anísio obteve um ganho em erudição, em conhecimento, em formação geral; no entanto, o mesmo não aconteceu com a sua fé. Ele mergulha no seu mundo interior e se dispõe a escrever as suas incertezas. Ao que parece, pretendia renovar a sua vida espiritual na sua viagem peregrina. No entanto, tem muitas dúvidas se isso aconteceu:

Relia hoje velhas cousas que havia escripto na minha viagem para a Europa. Até que ponto os meus desejos e minhas previsões se realizaram? De modo geral devo dizer que o aprendizado foi muito curto e que é muito cedo para tirar conclusões. Sob o lado technico ganhei evidentemente alguns conhecimentos novos. Sob o lado de formação geral, augmentei, é innegavel, o meu cabedal de cultura. Mas, a minha 
resposta sobre a influencia dessa viagem na qualidade_do meu espirito, será tão positiva? Se posso dizer que ganhei mais facilidade diante da vida, não deverei também dizer que ganhei mais banalidade diante da existência? E a minha fé, a minha comprehensão methaphysica da vida não está também cada vez mais afastada de mim, como um objecto de que eu conservo culto mas de que já não uso? (Teixeira, 1925).

Num primeiro instante Anísio tinha dúvidas, agora ele parece ter certeza que a sua viagem "não foi talvez outra cousa sinão uma dissipação do espírito e da intelligencia. O espirito dissipou-se na sua fé. A intelligencia diluiu ainda mais a sua cultura".

Se o viajante esteve diretamente com pessoas e situações ligadas à fé católica, o que poderia renovar os seus preceitos religiosos contribuiu mesmo foi para reformular suas crenças. Tarefa delicada, essa reformulação vai se definir e completar nos Estados Unidos da América. Ele apresenta uma imagem de um fiel se abrindo para o novo, disposto a conhecer e considerar formas novas de viver a sua fé.

Portanto, Anísio não se tornou o crente que fora na juventude em sua viagem aos países de ideário católico. Ele buscará esse propósito nos Estados Unidos. Escreve no seu diário sobre a necessidade de renovar a sua crença católica e acreditava que a América, o país voluntário por excelência e fortemente cristão, seria a fonte para uma renovação espiritual:

Oh! Essa nobresa do corpo, que só o catholicismo dá ainda a percebo e a estimo. O que preciso é de uma cura de vontade, cura de energia - e onde poderei ter mais intensa, mais efficas, mais penetradora do que na America, o paiz voluntario por excellencia? Se effectivamente, a vida como enriquecer o meu sentido de tolerancia e acepticismo, tem, do mesmo passo, enfraquecido o sentido da lucta e da rennuncia - que outro paiz melhor do que a America poderia renovar-me as fontes de acção, de energia e de apostolado e afastar - para sempre esse terrivel - não vale a pena - que é a tentação indefectível de uma intelligencia culta? Sob nenhum ponto de vista levo mais contentes e mais seguras esperanças. A America vai ser para mim, uma cura de vontade. (Teixeira, 1925).

O viajante se enganara. A América não renovou o seu antigo ardor pelo catolicismo. Pelo contrário, a sua fé enfraquecera-se mais ainda. Essa viagem de quatro meses nos Estados Unidos, comissionado para estudos de organização escolar, mudou, de acordo com Vianna Filho (1990), o pensamento de Anísio Teixeira. John Dewey, Kilpatrick e Counts - mais o exemplo concreto da experiência americana - transformaram a sua fé religiosa, tradicional, em fé nas possibilidades do homem, na melhoria da vida terrena, por meios dos métodos da educação inspirados na filosofia e na ciência.

De acordo com Hermes Lima (1978, p. 60), Anísio chegou católico aos Estados Unidos e de lá regressou liberto de qualquer crença revelada. "A crise religiosa conheceu ali o seu epílogo." Luís Viana Filho (1990, p. 31) também parece concordar com essa visão de Hermes Lima, pois, segundo ele, a América mudara a forma de pensar de Anísio: ele "conheceu o 
mundo que lhe mudou as convicções. Libertava-se graças às leituras de Dewey, filósofo que na América revolucionava a educação".

Conforme Fernando de Azevedo (1960, p. 31), ultrapassada a crise religiosa que sofreu na mocidade, Anísio orientou-se em outra direção, com a primeira experiência educacional na Bahia e seus estudos, entre 1928 e 1929, nos Estados Unidos. Foi um e voltou outro; partiu crente e voltou agnóstico: "A educação, a formação do homem, passou a ser a sua religião, como se sente no ardor quase religioso com que se consagrou ao apostolado leigo."

Anísio se desliga do modelo de católico mais tradicional, que outrora abraçara com tanto empenho, para adotar um novo registro eclesiológico, mais progressista. Ele permanece no rebanho católico, mudando, todavia, sua forma de conceber a fé. Definitivamente abre mão do desejo de ser jesuíta, adentrando um novo rumo.

Essas viagens também tiveram um impacto no seu pensamento político. Num primeiro momento Anísio se mostra a favor e saudosista do regime monárquico. É possível percebermos essa questão quando ele narra minuciosamente em seu diário de viagem à Europa a visita que realizara ao Conde de Mafra, deixando registrada sua admiração por essa emblemática figura do antigo regime. Antes de regressar definitivamente ao Brasil, visita o seu palacete localizado em Lisboa:

O Conde de Mafra é uma figura de simplicidade e distincção incomparáveis. Homem de intelligencia e de coração a sua vida é hoje um culto ininterrompido às velhas e boas cousas portuguesas banidas pela república. O seu palacete povoado de recordações de todos os reis da Europa e especialmente dessa corte portuguesa de que elle foi um dos grandes servidores é bem o quadro dessa sua vida. A saudade impregna tudo, mas nada entristece. O seu piedoso culto por tudo que a sua intelligencia verdadeiramente aprecia e o seu coração verdadeiramente estima não entristece a sua vida, nem a fas sossobrar em uma inatividade reprovavel. Alegre, jovial elle vive corajosamente a sua dor, que aflora aqui e alli, na conversa, no olhar, no gesto, mas logo apagada por um sorriso, por um disfarce amavel com que accentua o digno e sobranceiro pudor de sua alma. A nossa prosa ia e vinha livremente como um animal livre em um campo. Affinidades de pensamento, recordações que illustravam a nossa commum amizade a outro portugues de qualidades o Padre Luis Cabral - davam a nossa primeira palestra o encanto de um velho encontro de amigos. Apenas a minha inclassificável delicadeza multiplicava grosseiramente agradecimentos sem sentidos. (Teixeira, 1925).

Anísio registra a visita realizada ao Colégio de Campolide (antigo colégio dos jesuítas) junto com o Conde de Mafra. Ele descreve o trajeto, os seus sentimentos, emoções e tristezas por esse monumento que nunca mais voltaria a ser o mesmo. Chovia muito quando partiram. Desceram do bonde na rua Campolide, caminhavam apressados e silenciosos como se acompanhassem uma cerimônia fúnebre. Depois, defronte do colégio, as suas contemplações tinham qualquer coisa de piedoso, e as lágrimas escorriam de seus olhos.

O Conde de Mafra, segundo Anísio, não havia desejado voltar a esse local desde a revolução, pois era grande seu amor e saudosismo pelo 
colégio que lhe valera o título de antigo aluno honorário. Anísio prossegue na sua narração:

Na tristeza daquela manhã, o colégio de Campolide com os seus soldados em armas nas portas dava a idéia de um local privado vitimado por uma ocupação militar recente. Porque era ainda o collegio que estava diante de nós. Com o seu observatorio na torre, com a sua egreja, com o pedestal desarvorado de onde a Virgem presidia e abençoava o santo labor dessa casa. Apenas os fusis accentuavam indolentes que a occupação continuava. (Teixeira, 1925).

A República Portuguesa, de acordo com Anísio, exige a todos os professores universitários, como condição para receber os seus ordenados, uma profissão de fé republicana. Mas, o Conde de Mafra há quatro anos não recebe um centavo porque se recusa fazê-la. Pertencente a uma dinastia de servidores do rei jamais poderia fazer profissão de fé republicana. "Ah! o regime que permitte que um homem repita, com orgulho, que pertence a uma dynastia de servidores, é um grande regime" (Teixeira, 1925).

Se no diário de viagem à Europa Anísio se mostrava um saudosista do regime monárquico, agora, no diário de viagem à América do Norte, notaremos uma mudança de postura. Segundo ele, "afastada a possibilidade do regime forte e harmonioso que seria a monarchia - só nos resta aperfeiçoar a nossa republica" (Teixeira, 1925). Ele se revelará a favor de um regime livre e descentralizado:

Em política - A minha crença politica definitivamente se inclinou para os regimes descentralisados, facilitadores do florescimento das energias individuaes e das iniciativas pessoaes e que garantam uma exacta classificação social. Regime livre e justo. Livre, no sentido de não choibir, de nenhuma sorte, o desenvolvimento do individuo e da família; justo, no sentido de criar uma athmosphera onde os quadros sociaes se installem com sentido do merecimento e do valor justo, no sentido de permittir as aristocracias. (Teixeira, 1927).

Apesar de ser a favor de um regime livre, Anísio não deixará de apoiar a aristocracia, pois nesse momento ele pertencia a uma família aristocrata e tradicional do sertão baiano, os Spínolas e os Teixeiras, possuidores de grandes propriedades. Certamente será a favor da aristocracia, meio em que nascera e fora criado. Ele será totalmente contra esse regime quando volta dos Estados Unidos.

Democracia, conforme o viajante, tem sido no Brasil uma inversão de valores: as qualidades inferiores são exaltadas e os medíocres triunfam. A América, pelo contrário, permite uma democracia descentralizada, com o Estado reduzido ao mínimo, o que permite desenvolver um ambiente cultural, intelectual, moral, cívico e aristocrático. Anísio demonstra a sua admiração pelo regime democrático norte-americano, compara-o ao brasileiro, exalta o primeiro e condena o segundo:

A nossa democracia tem sido o regime das inversões de valores. Estamos longe de uma fixação honesta dos valores brasileiros. Pelo contrario o triumpho se está dando pelo melhor estado das qualidades inferiores 
5 No arquivo pessoal de Anísio encontram-se algumas cartas de recomendações que o autorizavam a realizar as visitas. Por meio dos seus timbres é possível compreendermos quais tipos de escolas foram visitadas: "Prefecture de la Seine. Directeur de L'Enseignement Primaire": "École Municipale des Arts Aplliqués a L'Industrie" e "Gabinete du Ministre de L'Instruction Publique et des Beaux Arts". que permittem os triumphos culpados de que somos testimunhas. A America vae mostrar-me uma democracia descentralisada, com o estado redusido ao minimo e em que um ambiente de cultura intelectual, moral e cívica permittem a formação de uma aristocracia. Como disse um escriptor celebre - a democracia americana encerra uma possibilidade de egualdade; as outras democracias tem procurado obter uma realidade de egualdade. Tanta é justa a primeira, quanto iníqua e revolucionaria a segunda. E' essa realidade de egualdade niveladora que cria nas democracias latinas dos melhores, para que se permitta o triumpho dos medíocres. (Teixeira, 1927).

No Brasil e na Europa o poder de uma classe dominante impedia a democracia e reeditava velhos princípios. Esses problemas, segundo Anísio, não teriam chances de existir na América, que valorizava a democracia, a liberdade e a igualdade de direitos.

Os seus conceitos sobre educação também serão reformulados. Quando partiu ao Velho Mundo, o seu pensamento pedagógico refletia ainda a marca do aristocratismo haurido da sua formação intelectual jesuítica, para o qual buscava, no sistema francês típico do dualismo classista, o ensino primário independente e isolado do secundário.

Na Europa Anísio visita algumas instituições educativas francesas e belgas. ${ }^{5}$ Como Diretor-Geral da Instrução Pública da Bahia e um viajante ávido por aprender, renovar seu conhecimento no campo que atuava, procura conhecer a educação estrangeira. Descreve a visita e trata dos programas, currículos, disciplinas, método e organização das escolas, porém, sem muito entusiasmo e surpresa:

Fui depois a escola normal maternal - école normal e gardienne - do estado para continuar a minha visita do dia anterior. Continuou a minha visita ser exatamente em dia de horário pouco interessante. A separação da escola normal para jardim de infancia é absolutamente recente na Bélgica. Mas essa emancipação está em vias de se tornar cada vez mais completa e mais nítida. Por enquanto a escola normal gardienne é um ensaio com muitas insufficiencias. O pessoal é commum, o material do ensino commum, apenas os programas differem, mas não bastante para permittirem a especialização necessária (Teixeira, 1924a).

Não havia nesse momento uma preocupação por parte de Anísio entre a prática pedagógica observada e a existência de uma concepção nova de modelo educacional que estava a se impor. Isso acontecerá somente por ocasião de sua visita aos sistemas educacionais norte-americanos em 1927. Até porque, ele partiu à Europa como um peregrino e não com a intenção maior de estudar instituições educativas. Suas visitas foram muito rápidas e localizadas.

É possível observar uma ambiguidade ou oscilação no pensamento educacional de Anísio quando em viagem aos Estados Unidos. Ele escreve no seu diário produzido a bordo que considerava "um absurdo as famílias pobres não poderem, no Brasil, oferecer uma educação católica aos seus filhos", acrescentando: "E isto é uma questão séria e incontestável". No entanto, não vai deixar de defender uma educação laica, republicana, e espera firmemente conhecê-la na prática no país considerado o modelo 
"ideal" de República. Segundo ele, "os moldes do seu pensamento sobre educação se moldaram na Europa. No entanto, hoje se aproximam vivamente dos americanos" (Teixeira, 1927).

Anísio, como outros intelectuais de sua época, acreditava que a educação americana se apresentava como uma experiência inédita, surgida em contraposição ao velho continente europeu, em que os fins da educação tiveram sempre alvos marcados e rígidos.

Os quatro meses nos Estados Unidos mudou a maneira de pensar de Anísio, pois, ao regressar ao Brasil, irá defender uma educação pública, gratuita e laica para todos. Não tinha porque a Igreja Católica administrar o ensino - isso era uma questão que somente cabia ao Estado.

Depois de suas visitas às instituições educativas norte-americanas, Anísio pôde comprovar que a escola dual europeia se resumia em fazer dos alunos ouvintes passivos. Diferentemente da escola única americana, que exaltava a individualidade e permitia a aprendizagem pela ação. Assim, ele reavaliará seus conceitos sobre a escola única.

No artigo produzido sob o título "A propósito da escola única", Anísio combateu esse tipo de escola preconizada por Carneiro Leão quando foi Diretor da Instrução Pública no Distrito Federal no período de 1922 a 1926. Ele avalia o impacto que o projeto da "escola única" exercia nos grandes centros e os efeitos comprometedores que poderia causar:

Se é verdade que o homem na sociedade tem direito ao desenvolvimento da inteligência em sua plenitude, daí não se segue que a organização de um instrumento único, idêntico para todos e a todos acessível, a "escola única" venha abrir para todos os homens a possibilidade de um pleno desenvolvimento de suas faculdades. (Teixeira, 1924).

Tal projeto, de acordo com Anísio, iria produzir o nivelamento intelectual e moral de um país, com a criação "de um tipo médio, sem grandes defeitos, porém sem grandes virtudes, tipo abstrato de cidadão, em que desaparecem todas as qualidades e particularidades individuaes" (Teixeira, 1924).

Segundo Bomeny (1993, p. 30), Anísio, nesse momento, estava dentro do "dilema tocquevilliano, qual seja, o de compatibilizar diferenças, liberdades individuais, com o princípio inexorável da igualdade, ideário condutor da sociedade moderna".

Para a autora, o modelo informado por Anísio é aquele que inspirou a Escola Nova norte-americana. Ou seja, como seria possível pensar em desenvolvimento idêntico para todas as inteligências de um país, se uma delas vai constituir a inteligência do camponês, do industrial, do letrado, do artista?

A "escola única", para Anísio Teixeira (1924), no seu aspecto fundamental, se apresentava em sua simplista uniformidade "desadequada para atender à variedade complicada da espécie humana e a sua aplicação como um possível e sempre desastroso nivelamento da inteligência de um país. 
A natureza humana é complexa e variada, diz Anísio, e qualquer projeto de nivelamento seria a sua destruição total. Assim ele procura justificar a sua posição contra a "escola única":

A inteligência de um dos nossos vaqueiros, por exemplo, de um daqueles sertanejos tão admiravelmente descritos por Euclides da Cunha, conhecedor da sua terra e das coisas da sua terra, sábio na arte de pastorear o seu gado e na equitação bárbara das caatingas, não tem a inteligência altamente desenvolvida para a melhor adaptação ao seu meio e à sua atividade? (Teixeira, 1924).

Anísio Teixeira (1924) acreditava que oferecer ao camponês, sertanejo, o homem da terra uma educação integral, num mesmo método e ensino igualmente ao intelectual requintado, era "desenraizá-los e inutilizá-los".

Não convém às sociedades democráticas modernas, diz Anísio, que ao filho do povo esteja somente reservado a escola primária e ao filho do rico o liceu; seria então necessário o liceu também ser uma oportunidade aos filhos do pobre, só que havendo uma seleção. Assim, os melhores alunos, entre ricos e pobres da escola primária, seriam admitidos no ensino secundário. A democracia garantiria o governo dos melhores, selecionados a partir do suposto básico do direito universal e gratuito à educação.

A postura e as ideias de Anísio vão se modificando. De acordo com Schaeffer (1998), ele, em sua carreira educacional de início, adotava uma postura tradicional e elitista, colocando-se contra a escola única; posteriormente, tornou-se um ardente defensor de uma educação comum para todo o povo brasileiro, combatendo uma educação de elites e de privilegiados. Sua visão da educação estava associada a uma dada concepção de filosofia e indissoluvelmente vinculada à ideia de construir uma sociedade democrática.

\section{Um olhar sobre os sujeitos: dizer o "outro" é representar a "si"}

Próximo destino de Anísio: Estados Unidos. Agora as suas observações e escrita voltar-se-ão especialmente aos sujeitos americanos. Isso se justifica pela intenção de sua viagem. Ele não se desloca a lazer, a peregrinação, passeio, mas sim a um trabalho de observação e análise da sociedade, política, cultura e educação norte-americana. As suas observações iniciam-se a bordo, na cotidianidade do navio:

O primeiro contacto com a America atravez deste navio, se tem sido um curto e pequeno contacto, não deixa de ser expressivo. Vivo entre um povo cordial e frio. No fundo é a eterna mola que faz com que tudo seja exacto, automatico, machinal, neste paiz. (Teixeira, 1927).

O outro contato é por meio da obra de Henry Ford. Segundo Anísio, a obra de Ford, My life and work, é bem uma preparação para visitar o país americano. Não conhece livro que produza uma profunda e positiva impressão de otimismo e confiança. 
Acabo de ler a obra de Ford, My life and work, que é bem uma preparação para visitar o pais americano. Não conheço livro que procura uma mais profunda e positiva impressão de optimismo e de confiança. Como as grandes obras de lucidez e clarividencia, não ha nesse livro logar para as phraseologias, o sentimentalismo, as hesitações. Tudo está tão unido, tão cerrado, tão nítido, que lembra a obra de Henry Ford um desses tratados definitivos sobre determinados assumptos, um desses livros que jorram uma tal quantidade de lus e verdade incontestaveis, que para sempre ficam como a pedra angular do assumpto, que poderá ser enriquecida de comentários, accrescida de detalhes - mas, sobre que sempre se há de apoiar a rasão humana. (Teixeira, 1927).

Anísio faz uma comparação dos livros de Ford e Inácio de Loyola. São obras radicalmente diferentes - uma de um industrial e outra de um religioso. Assim, é possível observarmos uma mudança operando no pensamento de Anísio: antes aparentando um devaneio à religião, à tradição e aos bons costumes, assolapados pela modernidade e a técnica; agora valorizando por igual o campo religioso e o campo industrial.

Em campos diversos - na vida espiritual um; na vida industrial, outro dois livros deram-me essa sensação de plenitude, de profundo accôrdo, de inexistencia de duvida - os exercícios espirituais de Ignácio de Loyola; My life and work de Henry Ford. Ambos tem esse traço caracteristico de unidade, de equilíbrio, de ligação que marca as obras que descobriram o contacto com a realidade. Esse realismo essencial, indestructivel que define a verdade e lhe dá essa força de golpe, de arremesso, com que taes livros nol'a communicam. (Teixeira, 1927).

Depois de suas leituras, o viajante passará às observações. Compara, admira, estranha e entende o estrangeiro como diferente. Constrói uma narrativa que pretendia dizer quem é o "outro". Na fenomenologia existencial de Sartre (2001) olhamos pra fora, observamos o "outro", e só assim somos capazes de voltar a nossa interioridade e conhecer a nós mesmos. É o "outro" que me identifica e julga.

Quem será esse "outro" tão diferente que causa fascinação e repulsa em Anísio Teixeira? Na medida em que críticas são feitas aos americanos, o viajante busca sempre a comparação com o seu padrão cultural tendo como referencial a cultura europeia.

É possível entender três momentos na narrativa de Anísio. A primeira trata das qualidades dos sujeitos observados - exaltações e admirações não faltam; a segunda demonstra estranhamento e receio por suas ações; e a terceira vai trazer à tona os defeitos, considerados pelo viajante como repugnantes, pois é o contrário de si, o que aprecia e acredita ser o correto.

O olhar, segundo Sartre (2001), não é neutro: ele avalia e atribui julgamentos de valores que são, ao mesmo tempo, verdadeiros e falsos. Assim, é possível dizer que elementos ficcionais e reais estavam presentes na escrita de Anísio.

No navio em que Anísio viajava havia povos de várias nacionalidades - argentinos, franceses, filipinos, mexicanos, entre outros. No entanto, o seu olhar volta-se somente ao povo americano. Com que olhar ele observa esses sujeitos? Um olhar subjetivo, objetivo, crítico, reflexivo, preconceituoso, atento, desatento ou investigativo? Todos eles. 
De acordo com Anísio, o americano tem a liderança do mundo pelo trabalho e pelo progresso. Isso o leva a analisar a sua realidade, a realidade do Brasil, contrária à dos Estados Unidos. Dessa forma, o exemplo americano de sociedade, cultura, educação e trabalho são referenciais e modelares.

Anísio reconhece a si como pertencente aos povos latinos, cismadores e tristes, diferente dos americanos, alegres e humorados. Porém, há um segundo momento da narrativa em que o viajante reconhece os defeitos dos americanos: "Elles são uma tal demonstração de energia que se torna o seu ambiente, levemente arrogante, insolente, indesejável" (Teixeira, 1927).

Percebendo o diferente, o viajante passou a enxergar a si também como um diferente, e entender que havia pessoas com tradição e educação distinta da sua. A cultura europeia, aprendida em família e nos colégios jesuítas, passa a não ser o único referencial. Existiam outros costumes, mesmo que esses fossem uma desestruturação do então acreditado e aceito.

Anísio sempre estava atento aos acontecimentos cotidianos a bordo envolvendo os americanos. Seguia pistas, vestígios, descrevia, analisava, comparava, expressava de modo indireto uma imagem do americano. Sempre atento, vendo, ouvindo, presenciando, atestando e registrando o que dizia respeito a esses sujeitos.

Ele tentou reproduzir na sua escrita o como são, o que são, o que fazem, como fazem esses sujeitos. Por uma parte ínfima de americanos presentes no navio tentou reconstruir uma sociedade de americanos; evidentemente que suas leituras sobre esse povo o ajudaram na sua reconstituição.

Apesar de suas atentas observações, Anísio se deixou levar pelas aparências. Um contato de duas semanas entre pessoas dentro de um navio não daria conta para afirmar algo sobre alguém. Anísio também não levou em conta o contexto situacional, as emoções e os sentimentos ali vividos. O que ele dizia serem aqueles americanos não se resumia entender que todos os americanos eram e agiam daquela forma.

O que o viajante registrou não é uma verdade incontestável, uma autenticidade dos fatos, mas sim uma versão, fragmentos da realidade. Ele produziu, em certo sentido, uma pequena história situacional dos sujeitos. É possível dizer que ele "inventou" o jeito, a maneira de ser do americano.

Inicialmente o observador atenta para as características físicas e psicológicas desse povo. Segundo ele, os americanos não conversam riem. Em sua mesa encontra-se uma senhora, muito alegre, muito risonha, o que nada falta "para ser uma legítima americana, nem a nasalidade de uma lingoa difficilima de perceber; nem a liberdade masculina de conversar; nem essa energia amarga de uma raça forte e positiva". (Teixeira, 1927). Ao seu lado senta-se um americano moreno, cuja origem não descobre, e que tem uma "socegada e tranquilla alegria, sem irritações e sem difficuldades". "Um americano de origem francamente alemã, mas participante desse bom humor nacional", se encontra junto do viajante. 
Do outro lado, um senhor moço, "também alegre e tambem pratico". No centro, o engenheiro chefe de bordo: "um velho, de rosto liso e energia intacta, de riso contente e fácil". E, por fim, Anísio faz uma consideração:

Como se vê o primeiro traço que percebo do americano é o da satisfação. Dahi, esse aspecto raro: não vejo nenhum americano antipathico. Todos têm essa alegria um nadinha mechanica e como artificial, mas que lhes dá um ar de sympathia, de victoria. (Teixeira, 1927).

Para dizer o "outro" Anísio também dispõe da comparação. A sua escrita é repleta de elementos comparativos: compara seus companheiros de navio, os americanos, aos latino-americanos. Evidentemente que exalta as qualidades dos primeiros em detrimento dos segundos:

Fasem a vida com esse bom humor, esse calculo, essa acceitação que os impede de estar tristes. Ha, em tudo, para nós um pouquinho de montagem. Para elles - entre o espirito que fomos, por veses, em uma funcção, em um dever, e o que temos diante da vida, em geral, não ha differença. Esse fundo de sonho, de hesitação, de incosciencia, de mysterio que nos faz a nós latinos - scimadores e tristes - elles não o conhecem, nem o querem conhecer. O lado positivo, o footh da vida, os absorve e lhes basta. Reflectindo-se, vê-se que elles tem rasão. Mas, os americanos têm sempre rasão, sempre lógica - o que não quer dizer que tenham da vida o seu sentido completo e difficil. (Teixeira, 1927).

Continuando as suas observações e registros, o viajante diz que, nos passeios do tombadilho, ou reunida nos salões, ou animada pelo prazer do esporte e da dança, é sempre a mesma sociedade satisfeita e à vontade, superiormente instalada na vida, divertindo-se com ruído, alegre e satisfeita. "É uma raça unificada. Pode-se assim resumir o conceito que se poderá fazer sobre esse grande povo, que vive a vida com a precisão e a dignidade de uma machina" (Teixeira, 1927 - grifo do autor).

À medida que os dias vão se passando dentro do navio, Anísio começa a conhecer mais sobre americanos. Num primeiro momento, exaltava somente as suas qualidades, depois estranha algumas atitudes e, por fim, reconhece os seus defeitos.

A satisfação, a falta de etiqueta e de formalismo, a sobriedade (um unico prato em cada refeição), a marcha forte, atirada, de arremesso, que se torna visivel sobretudo entre as mulheres, a facilidade infantil de se distrahir, a completa ausencia de espirito, no sentido latino da palavra, o gosto dos sports e da dança (que alias parece-me menos intensa) são as linhas em que se encaderna este povo, que se pretende e que tem de facto a liderança do mundo. (Teixeira, 1927).

Anísio narra fatos considerados estranhos. Assim registra um pequeno incidente que lhe revelou a natureza do americano. Ao chegar à sala de jantar, o garçon indica o seu lugar. Chegam os demais companheiros de mesa e, então, o garçon apresenta-lhes como um verdadeiro mestre de cerimônia. Os americanos apertam-lhe a mão afetuosamente. Contava ter por aí adiante verdadeiros amigos, mas Anísio se decepciona: 
Nada disto. Cumpriram praticamente, machinalmente aquelle dever - e acabou-se. Depois, o cumprimento sempre muito cordial não tem faltado, mas fica ahi. E a conversa da mesa transcorre entre os patrícios - muito cheia de risos e quase sem palavras. (Teixeira, 1927).

Outro episódio ocorrido surpreende Anísio - ele descreve uma sessão de luta de boxe. Participavam da luta jogadores franceses, americanos e filipinos. "Venho desta reunião, e os meus nervos ainda estão a tremer da violência e dessas luctas humanas". O sangue escorria das faces dos jogadores, e "havia nos ultimos rounds essa lentidão penosa e violenta dos esforços máximos". Tudo era assistido com risos, alegria e festa. "É um traço característico desse povo essencialmente forte. Como tudo isto se coordena com o hard book que podia ser a divisa da gente americana". Em tudo e para tudo levam eles esse superávit de energia e essa ausência de falso sentimentalismo, diz Anísio. Finalizando sua narrativa, acredita que a sessão não foi interessante, porém ficou registrada essa documentação dos bons nervos americanos: "Não surprehende. Mas, o observador estima essas confirmações" (Teixeira, 1927).

Agora há uma inversão, ou uma nova versão de olhar o sujeito americano. O registro das qualidades dessa gente é deixado de lado, e os defeitos são postos à vista. De acordo com Hartog (1999), o princípio da inversão é uma maneira de transcrever a alteridade, tornando-a fácil de apreender no mundo em que se conta. Entretanto, pode funcionar também como um princípio heurístico, permitindo compreender, considerar, dar sentido a uma alteridade.

Anísio não deixa de reconhecer os defeitos dos americanos, apesar de sua admiração por eles. Estranha esse "outro" que lhe parecia tão querido, agradável e cheio de virtudes, pois, segundo Hartog (1999, p. 231), "a inversão é uma ficção que faz 'ver' e que se faz compreender".

Mas a sua falta de... formalismo, a sua sans façon é realmente de arrepiar. À noite, ao jantar, as toilettes... Santo Deus! Ha os calções de cyclistas, os casacos de sports mais variados, os colletes de lã a dispensarem casacos, ha as combinações mais insolentes e mais grotescas que se podem imaginar! Hoje havia um que trasia smoking e calça branca enxovalhada. Aos jantares, é commum tomar a palavra um dos senhores e dizer pilherias, sob pretexto de annunciar qualquer cousa, que ficam perfeitamente bem em um palhaço. Outro, lembra-se de cantar qualquer cousa, em pleno jantar e é, vivamente applaudido. E toda essa gente vive a bordo como se estivesse em sua casa. Pela manhã enche-se a piscina. Toma-se café. Ou melhor, almoça-se, e de verdade. Lê-se, conversa-se, passeia-se. As 11/12, corridas de cavallos. Aposta-se. Lancha-se as 13 horas. Ha jogos sportivos até as 18. As 19 janta-se. Até as 23 dança-se ou então ha alguma sessão especial, como ontem, a de Box. Como amanhã em que haverá baile de mascaras. Confirma-se, para mim, aquella theoria dos American Shocks. Dentro dessa cordialidade esse povo repelle as qualidades mais delicadas do espirito, por serem fracas. (Teixeira, 1927).

Apesar desse olhar negativo sobre os sujeitos americanos, que segundo Anísio têm a liderança no mundo pelo dólar, pelo trabalho, pela ciência, pela técnica e pelo progresso, ele faz uma observação: 
Não nos precepitemos, porem. Continuo a supportar as suas pisadas de soldado em marcha diante de minha cadeira de bordo, as suas ruidoras expanssões para que me seja possível conhecer alguma cousa dessa extraordinária alma americana. (Teixeira, 1927).

Finalizando suas reflexões sobre o povo americano, Anísio diz que, se continuasse as suas observações de bordo, "seria indispensavel fixar aqui alguns typos bastantes característicos, dentre os habitantes desse pequeno mundo, de breve duração, mas tão interessante, de um navio". No entanto, não se destina a tais observações. Basta para o viajante "o traço geral".

Viajar, além de comparar, também é refletir. É estar com os olhos aguçados e os ouvidos bem abertos para recolher impressões produzidas por estes sentidos, a visão e a audição, permitindo um constante pensar o "eu" e o "outro", o igual e o diferente, e buscar compreender o porquê das diferenças.

O que cada um observa e registra é resultado da maneira, do lugar e do momento situacional que se escolhe ver. Nesse olhar, muitas vezes estão embutidos crenças culturais, religiosas, costumes, hábitos, formas de ser, de agir e sentir, tensões, opiniões, desejos e sentimentos. O olhar não é linear, tem muitas direções, curvas e obstáculos.

Além de que, cada um tem a sua própria forma de ver as coisas e o seu ponto de vista; como tal, não conseguimos obter uma análise integrada da realidade, apenas uma realidade inteligível. E as interpretações de uma determinada coisa ou sujeito podem e são as mais diversificadas possíveis. A realidade é móvel, e sua percepção depende da visão de quem a lê/vê.

\section{Considerações finais}

A narrativa de Anísio sobre "si" e sobre o "outro" é, portanto, como qualquer discurso, uma produção humana entrecortada de ficção. Desse modo, na sua escrita operam fragmentos da realidade, imaginação, disfarce, silêncio, esquecimento, lapsos, seleção do que vai ser registrado. E isso não é uma dádiva à maneira de escrever de Anísio Teixeira, mas inerente a qualquer escritor.

Bourdieu (1996, p. 185), citando Allain Robbe-Grillet, afirma que "o real é descontínuo, formado de elementos justapostos sem razão, todos eles únicos e tanto mais difíceis de serem apreendidos porque surgem de modo incessantemente imprevisto, fora de propósito, aleatório".

Muitos teóricos se perguntam se há realmente um traço formal que separe a narração de acontecimentos verificáveis da narração produzida pelo imaginário (Alberti, 1991). Segundo Leite (1993, p. 6), "Quem narra narra o que viu, o que viveu, o que testemunhou, mas também o que imaginou, o que sonhou, o que desejou. Por isso, a narração e a ficção praticamente nascem juntas".

Se essa narrativa contém as impressões de Anísio sobre o que ele pensa, a maneira como pensa, já é decerto um precioso indicativo das 
suas idéias e pensamentos. Evidentemente que ele se valeu da ficção, da criação, para escrever sobre "si" e sobre o "outro". No entanto, é preciso lembrar que o fictício não é sinônimo de falso - o real passa pelo imaginário de um escritor.

No discurso de Anísio sobre o outro e sobre si operam, de um lado, a descontinuidade, a dispersão, a incompletude, a falta, o equívoco, a contradição e, por outro, a unidade, a completude, a coerência, a não contradição. É por essa articulação sempre presente entre o real e o imaginário que o discurso funciona.

Conforme Gomes (2004, p. 14), a escrita de si assume a subjetividade de seu autor como dimensão integrante de sua linguagem, construindo sobre ela "a sua verdade". Dessa forma, torna-se necessário ao pesquisador atentar-se à ótica assumida pelo registro em como seu autor a expressa. Isto é, "o documento não trata de "dizer o que houve", mas de dizer o que o autor diz que viu, sentiu e experimentou, retrospectivamente, em relação a um acontecimento".

A autora nos alerta a compreender a escrita pessoal não como uma verdade a ser revelada por quem a escreveu. Não se pode correr o risco de acreditar que a fonte seja expressão de uma verdade descoberta, mas sim entendê-la como um registro por parte de seu autor, de suas impressões e pontos de vista.

O pesquisador deve fazer uso dessas narrativas sabendo que elas são construídas por sujeitos históricos - cuja formação, intenção, visão de mundo e objetivo podem influir decisivamente na tessitura dos seus textos.

A realidade é algo pensado, imaginado por sujeitos; jamais se pensa neutro. Certamente a visão de mundo de Anísio Teixeira, o que considerava certo de acordo com seus padrões sociais, culturais, políticos e ideológicos, irá refletir na sua escrita.

\section{Referências bibliográficas}

ALBERTI, Verena. Literatura e autobiografia: a questão do sujeito na narrativa. Estudos Históricos, Rio de Janeiro, v. 4, n. 7, p. 66-81, 1991. Disponível em: <http://bibliotecadigital.fgv.br/ojs/index.php/reh/article/ view/2313/1452>.

AZEVEDO, Fernando de. Anísio Teixeira ou a inteligência. In: AZEVEDO, Fernando de et al. Anísio Teixeira: pensamento e ação. Rio de Janeiro: Civilização Brasileira, 1960. p. 27-34.

BOMENY, Helena. Novos talentos, vícios antigos: os renovadores e a política educacional. Estudos Históricos, Rio de Janeiro, v. 6, n. 11, p. 24-39, 1993. Disponível em: < http://bibliotecadigital.fgv.br/ojs/index. php/reh/article/view/1955/1094>. 
BOURDIEU, Pierre. A ilusão biográfica. In: FERREIRA, Marieta de Moraes; AMADO, Janaína (Orgs.). Usos e abusos da história oral. Rio de Janeiro: Fundação Getúlio Vargas, 1996. p. 25-39.

BOURDIEU, Pierre. Espaço social e poder simbólico. In: . Coisas ditas. São Paulo: Brasiliense, 2004. p. 149-168.

CARVALHO, Marta Maria Chagas de. Anísio Teixeira: itinerários. In: . A escola e a República e outros ensaios. Bragança Paulista: Edusf, 2003. p. 165-193.

COSTA, Marcelo Timotheo. De volta à Estação Europa: relatos de viagem e mudança em Alceu Amoroso Lima. Estudos Históricos, Rio de Janeiro, v. 1, n. 35, p. 139-158, 2005. Disponível em: <http:// bibliotecadigital.fgv.br/ojs/index.php/reh/article/view/2234/1373>.

ECO, Umberto. Interpretação e superinterpretação. São Paulo: Martins Fontes, 2005.

GOMES, Ângela de Castro (Org.). Escrita de si, escrita da História. Rio de Janeiro: FGV, 2004.

HARTOG, François. O espelho de Heródoto: ensaios sobre a representação do outro. Belo Horizonte: UFMG, 1999.

LEITE, Ligia Chiappini Moraes. O foco narrativo. São Paulo: Ática, 1993.

LIMA, Hermes. Anísio Teixeira: estadista da educação. Rio de Janeiro: Civilização Brasileira, 1978.

MIGNOT, Ana Chrystina Venâncio. Papéis guardados. Rio de Janeiro: Uerj/Rede Sirius, 2003.

MIGNOT, Ana Chrystina Venâncio. Entre cartas e cartões postais: uma inspiradora travessia. In: MIGNOT, Ana Chrystina Venâncio; GONDRA, José (Org.). Viagens pedagógicas. São Paulo: Cortez, 2007. p. 246-276.

MIGNOT, Ana Chrystina Venâncio; GONDRA, José Gonçalves. A descoberta da América. In: NUNES, Clarice (Org.). Aspectos americanos de educação \& anotações de viagem aos Estados Unidos em 1927. Rio de Janeiro: Ed. UFRJ, 2006. p. 9-24.

NUNES, Clarice. Anísio Teixeira: a poesia da ação. Bragança Paulista: Edusf, 2000.

PINO, Cláudia Amigo. A ficção da escrita. Cotia: Ateliê Editorial, 2004. 
SARTRE, J. P. O ser e o nada. Petrópolis: Vozes, 2001.

SCHAEFFER, Maria Lúcia Garcia Palhares. Anísio Teixeira: formação e primeiras realizações. São Paulo: USP/Faculdade de Educação, 1988.

TEIXEIRA, Anísio. A propósito da "Escola Única". Nov. 1924, 7 folhas mimeografadas. Arquivo Anísio Teixeira, CPDOC/FGV, terceiro rolo, 2(0445). [Publicado na Revista do Ensino, Salvador, v. 1, n. 3, 1924. Disponível em: < http://www.bvanisioteixeira.ufba.br/artigos/proesc. htm > ].

TEIXEIRA, Anísio. Anotações de viagem à Europa. Lisboa, 1925, 56 p. Atpi: 25.07.17 (filme 03). FGV/CPDOC. Disponível em: < http://www. bvanisioteixeira.ufba.br/artigos/viagemEuropa.html $>$.

TEIXEIRA, Anísio. Anotações de viagem aos Estados Unidos. Navio Pan American, 1927, 50 p. Atpi: 25.07.17 (filme 03). FGV/CPDOC. Disponível em: <http://www.bvanisioteixeira.ufba.br/ineditos.html>.

VIANNA FILHO, Luís. Anísio Teixeira: a polêmica da educação. Rio de Janeiro: Nova Fronteira, 1990.

VIÑAO, Antonio. Las autobiografias, memorias y diários como fuente histórico-educativa: tipologia y usos. Revista Teias, Rio de Janeiro, v. 1, n. 1, p. 82- 95, jun. 2000.

Silmara Fatima Cardoso é doutoranda em Educação na Universidade de São Paulo (USP).

sfcardoso2011@hotmail.com

Recebido em 11 de novembro de 2011.

Aprovado em 7 de novembro de 2012. 